\title{
Glucose Transporter Levels in Spontaneously Obese (db/db) Insulin-resistant Mice
}

\author{
Laszlo Koranyi, David James," Mike Mueckler," and M. Alan Permutt \\ Metabolism Division, Department of Internal Medicine, and *Department of Cell Biology, \\ Washington University School of Medicine, St. Louis, Missouri 63110
}

\begin{abstract}
In the present study we examined mRNA and protein levels for the muscle/adipose tissue glucose transporter (GLUT-4) in various tissues of spontaneously obese mice (C57BL/KsJ, $\mathrm{db} / \mathrm{db})$ and their lean littermates $(\mathrm{db} /+)$. Obese $(\mathrm{db} / \mathrm{db})$ mice were studied at 5 wk of age, when they were rapidly gaining weight and were severely insulin resistant, evidenced by hyperglycemia (plasma glucose $683 \pm 60$ vs. $169 \pm 4 \mathrm{mg} / \mathrm{dl}$ in $\mathrm{db} /+, P$ $<0.05$ ) and hyperinsulinemia (ṕlasma insulin $14.9 \pm 0.53$ vs. $1.52 \pm 0.08 \mathrm{ng} / \mathrm{ml}$ in $\mathrm{db} /+, P<0.05)$. The GLUT $-4 \mathrm{mRNA}$ was reduced in quadriceps muscle $(67.5 \pm 8.5 \%, P=0.02)$, but unaltered in adipose tissue $(120 \pm 19 \%$, NS), heart $(95.7 \pm 6.1 \%$, NS), or diaphragm $(75.2 \pm 12.1 \%, \mathrm{NS})$ in obese $(\mathrm{db} / \mathrm{db}) \mathrm{mice}$ relative to levels in lean littermates. The GLUT-4 protein, measured by quantitative immunoblot analysis using two different GLUT-4 specific antibodies, was not different in five insulin-sénsitive tissues including diaphragm, heart, red and white quadriceps muscle, and adipose tissue of obese $(\mathrm{db} / \mathrm{db})$ mice compared with tissue levels in lean littermates; these findings were consistent when measured relative to tissue DNA levels as an index of cell number. These data suggest that the marked defect in glucose utilization previously described in skeletal muscle of these young obese mice is not due to a decrease in the level of the major muscle glucose transporter. An alternate step in insulin-dependent activation of the glucose transport process is probably involved. (J. Clin. Invest. 1990. 85:962-967.) muscle/adipose tissue - GLUT -4 glucose transporter mRNA • insulin resistance • obese $(\mathrm{db} / \mathrm{db})$ mice
\end{abstract}

\section{Introduction}

Non-insulin dependent diabetes mellitus (NIDDM) ${ }^{1}$ is a heterogeneous disease that is probably polygenic in nature. One of

Address correspondence to Dr. M. Alan Permutt, Department of Internal Medicine, Metabolism Division, Washington University School of Medicine, Box 8127, 660 South Euclid Avenue, St. Louis, MO 63110 .

Received for publication 31 August 1989 and in revised form 30 October 1989.

1. Abbreviations used in this paper: $\mathrm{db}$, diabetes; NIDDM, non-insulin dependent diabetes mellitus.

J. Clin. Invest.

(c) The American Society for Clinical Investigation, Inc.

0021-9738/90/03/0962/06 \$2.00

Volume 85, March 1990, 962-967 the major pathophysiological disorders of NIDDM is peripheral insulin resistance. This appears to be due at least in part to a defect in muscle tissue, the major site of whole body insulindependent glucose disposal $(1,2)$. One possible candidate for this defect is the glucose transporter, because glucose transport appears to be the rate-limiting step for glucose utilization in muscle (3).

Facilitated diffusion glucose transport is catalyzed by a family of tissue-specific proteins $(4,5)$. These include: the HepG2-type transporter (GLUT-1) which is ubiquitously expressed in mammalian tissues but is present at highest levels in brain, placenta, and erythrocytes $(6,7)$; the liver-type transporter (GLUT-2) which is present in splanchnic tissues, kidney, and pancreatic islets $(8,9)$; and the muscle/adipose tissue transporter (GLUT-4) which is expressed in tissues that exhibit insulin-dependent glucose transport, i.e., muscle and fat (10-14). Therefore, defective whole body glucose homeostasis due to defects in specific tissues, as is observed in NIDDM, could hypothetically arise from a lesion in any one of these glucose transporters.

Spontaneously obese mice have been a useful model for genetic analysis of insulin resistance and diabetes susceptibility (15). The diabetes (db) mutation on chromosome 4 in the homozygous conditions produces hyperphagia, progressive obesity, insulin resistance, and hyperglycemia, a syndrome similar to NIDDM in man. The initial adaptation to the insulin resistance is one of islet beta cell hyperplasia resulting in marked hyperinsulinemia, but ultimately islets develop beta cell necrosis, insulinopenia, severe hyperglycemia, and weight loss (16). The response to the obesity-induced insulin resistance in mice differs according to the inbred strain, and genetic analysis has provided evidence that multiple genes are involved $(17,18)$.

Previous studies have shown that insulin-stimulated glucose transport in muscle is impaired in the $\mathrm{db} / \mathrm{db}$ mouse (19-22). Because glucose transport appears to be the rate-limiting step for glucose utilization in skeletal muscle (23), these data implicate this initial step as a potential locus for the defect resulting in insulin resistance. Such a defect could encompass the glucose transporter per se, or part of the signal transduction pathway whereby insulin augments glucose transport. The insulin resistance of streptozotocin diabetic and fasted rats has recently been extensively characterized in adipose cells (24-27). In these insulin-resistant states, decreased glucose transport activity was shown to correlate closely with decreased muscle/adipose tissue glucose transporter mRNA and protein. In the present study we measured tissue glucose transporter mRNA and protein levels in spontaneously obese $(\mathrm{db} /$ $\mathrm{db})$ mice relative to those in lean $(\mathrm{db} /+)$ littermates to further 
define the defect in glucose utilization at the biochemical level. The results indicate that changes in the steady-state level of GLUT-4 protein cannot account for the defect in peripheral glucose uptake observed in obese $(\mathrm{db} / \mathrm{db})$ mice.

\section{Methods}

Animals. Inbred strains of mice were purchased from the Jackson Laboratory (Bar Harbor, ME). Mice were fed a standard diet of Purina Rat Chow (Ralston Purina Co., St. Louis, MO) and tap water ad lib up until the time of study. Male mice $5 \mathrm{wk}$ of age were used exclusively for experimentation. Obese hyperglycemic $\mathrm{C} 57 \mathrm{BL} / \mathrm{KsJ}(\mathrm{db} / \mathrm{db})$ mice were studied relative to $\mathrm{C} 57 \mathrm{BL} / \mathrm{KsJ}(\mathrm{db} /+)$ lean littermates. At $5 \mathrm{wk}$ of age the $\mathrm{db} / \mathrm{db}$ mice are obese, hyperglycemic, and hyperinsulinemic.

Tissue and blood sampling. The mice were killed in the fed state using pentobarbitol sodium $(100 \mathrm{mg} / \mathrm{kg}$, i.p.). Blood was collected from the orbital sinus and then pancreas, quadriceps, and gastrocnemius muscle, diaphragm, epididymal fat pads, and heart were removed, weighed, frozen in liquid nitrogen, and stored at $-70^{\circ} \mathrm{C}$ until analysis.

cDNA probes, synthetic $m R N A$ standards, and antibodies. The cDNA probes used for study were as follows: $(a)$ a mouse proinsulin I cDNA fragment isolated from a mouse pancreatic cDNA library (28), (b) the muscle/adipose tissue glucose transporter (GLUT-4) cDNA, isolated from rat adipocyte and heart cDNA libraries as described (10), and $(c)$ a plasmid containing 1,200 bp of chicken beta-actin cDNA. Each cDNA insert was subcloned into a pGEM (Promega Biotec, Madison, WI), or Bluescript SK+ (Stratagene, San Diego, CA) plasmid and transcription of uniformly labeled $\left[{ }^{32} \mathrm{P}\right] \mathrm{cRNA}$ and synthetic mRNA with T3 or T7 RNA polymerase was performed according to protocols provided by suppliers.

Two antibodies specific for the rat muscle/adipose tissue glucose transporter were used for immunoblotting. A monoclonal antibody (IF8), raised against rat adipocyte GLUT-4 (13), was used at a serum concentration such that the final concentration of protein was 10 $\mu \mathrm{g} / \mathrm{ml}$. A polyclonal antibody (R820), specific for a carboxy-terminal synthetic peptide of insulin-regulatable glucose transporter (10), was used by diluting serum to a final protein concentration of $5 \mu \mathrm{g} / \mathrm{ml}$.

Quantitation of $m R N A s$ and DNA. Total tissue RNA was extracted using a guanidine thiocyanate method (29). All samples had $28 \mathrm{~S} / 18 \mathrm{~S}$ RNA ratios over 2.0 on ethidium bromide staining after electrophoresis on agarose gels, and also showed discrete actin mRNA bands on Northern blot analysis.

Initial studies to validate the specificity of each cRNA probe were performed using Northern analysis. Once the appropriate stringency for hybridization of each clone was established, quantitation of mRNA levels between the mice was performed using dot blot analysis. Aliquots of total tissue RNA (1-10 $\mu \mathrm{g})$ and dilutions of synthetic mRNA $(0.5-1,000 \mathrm{pg})$ and of cDNA (1-1,000 pg) as standards were dissolved in $15 \%$ formaldehyde/10 $\times$ standard saline citrate (SSC) and blotted onto Nytran (Schleicher \& Schuell, Inc., Keene, NH) membranes. Membranes were hybridized to the corresponding probes for 16-18 h (proinsulin and GLUT-4 at $60^{\circ} \mathrm{C}$, actin at $55^{\circ} \mathrm{C}$ ) in $50 \%$ formamide, $5 \times$ SSPE, and then washed (proinsulin and GLUT -4 at $60^{\circ} \mathrm{C}$, actin at $52^{\circ} \mathrm{C}$ ) in $0.1 \times \mathrm{SSC}, 0.1 \% \mathrm{SDS}$, according to the instructions recommended by the vendor. Blots were exposed to Kodak XAR5 film at $-70^{\circ} \mathrm{C}$ using intensifying screens (Cronex Lightening Plus; E. I. Dupont de Nemours Co., Wilmington, DE). The amount of mRNA present in each sample, determined in duplicate, was measured by densitometric analysis, comparing the intensity of the sample dot with standard dots. Autoradiographs were developed for various periods of time so that the intensity of the unknown samples was within the linear range of the standards.

DNA was measured in crude tissue homogenates by a spectrofluorometric assay (30).

Immunoblotting. In preparation for SDS-PAGE, tissue samples were diluted 1:10 (wt/vd) with ice-cold PBS (pH 7.4) and immediately homogenized using a Brinkmann homogenizer (Brinkmann Instruments, Inc., Westbury, NY). Protein determinations were performed on each sample using the bicinchinoic acid procedure (Pierce Chemical Co., Rockford, IL). 50- $\mu \mathrm{g}$ samples of each tissue homogenate were diluted with Laemmli sample buffer and subjected to SDS-PAGE using a $10 \%$ acrylamide resolving gel. Proteins were electrophoretically transferred to nitrocellulose sheets, which were immunoblotted as previously described (10-13). Homogenates of diaphragm, red quadriceps, and heart from control and $\mathrm{db} / \mathrm{db}$ mice were immunoblotted on separate occasions to ensure reproducibility. A protein migrating at 45 $\mathrm{kD}$ was immunolabeled by anti-GLUT-4 antisera in all muscle and adipose tissue samples. Quantitation of the band labeled with either IF8 and iodinated sheep anti-mouse IgG (Amersham Corp., Arlington Heights, IL) or with R820 and iodinated protein A (Amersham Corp.) was performed by excising the corresponding piece of nitrocellulose and counting in a gamma counter.

Glucose and insulin determinations. Frozen aliquots of pancreas were homogenized with a Polytron homogenizer (Brinkmann Instruments, Inc., Westbury, NY) and subjected to acid-ethanol insulin extraction (16). Plasma and pancreatic insulin concentrations were measured by a double antibody radioimmunoassay using rat insulin standards (Novo, Copenhagen, Denmark), and plasma glucose by a glucose-6-phosphate dehydrogenase method (Sigma Chemical Co., St. Louis, MO).

Data analysis. Comparisons between C57BL/KsJ db/db and $+/ \mathrm{db}$ mice were performed using a nonpaired $t$ test using the CLINFO Program on a VAX computer.

\section{Results}

Expression of glucose transporter MRNAs in spontaneously obese diabetic $(\mathrm{db} / \mathrm{db})$ mice. Observations were made using obese (db/db) mice at $5 \mathrm{wk}$ of age. As previously noted, at this age the mice are obese (body weight $163 \pm 4.4 \%$, mean \pm SE, $P$ $<0.01$ ), hyperglycemic (plasma glucose $391 \pm 36 \%, P<0.01$ ), and hyperinsulinemic (plasma insulin $976 \pm 228 \%, P<0.001$ ) compared with lean $(\mathrm{db} /+)$ littermates (Table I). Pancreatic weight $(101 \pm 6.9 \%, \mathrm{NS})$ and RNA concentration $(89.1 \pm 10.8 \%$, NS) did not differ between the groups, but insulin content was decreased $(21.9 \pm 4.3 \%, P<0.001)$, and proinsulin mRNA concentration was increased $(211 \pm 23 \%, P<0.001)$ in $\mathrm{db} / \mathrm{db}$ mice relative to that in lean littermates. While $\mathrm{db} / \mathrm{db}$ mice are diabetic defined by hyperglycemia, higher values for proinsulin mRNA, lower pancreatic insulin stores, and higher plasma insulin levels were all consistent with a greater rate of insulin synthesis and release in obese $(\mathrm{db} / \mathrm{db})$ mice, and contrast with low values of proinsulin mRNA and plasma insulin in previously studied streptozotocin diabetic animals (24-27).

To determine whether the marked differences in fed plasma glucose and insulin between the two groups of mice could be accounted for by different levels of GLUT-4 gene expression, mRNA levels were quantitated in diaphragm, heart, skeletal muscle, and adipose tissue. Initial studies with GLUT-4 and the HepG2/erythrocyte (GLUT-1) cDNA probes indicated that the ratio of GLUT-4 to GLUT-1 mRNA was 80:1 in rat skeletal muscle and 60:1 in mouse heart. Once these studies defined the major GT mRNA in these tissues, quantitation of GLUT-4 mRNA levels was accomplished by dot blot analysis using synthetic mRNA standards (Table II).

Total tissue RNA (Table II) and DNA (Table III) did not differ between $\mathrm{db} / \mathrm{db}$ and $\mathrm{db} /+$ mice, except in adipose tissue where both RNA $(P<0.05)$ and DNA $(P<0.05)$ were reduced in $\mathrm{db} / \mathrm{db}$ mice. The GLUT-4 mRNA concentration (Table II) was reduced in quadriceps $(67.5 \pm 8.5 \%, P<0.02)$ of $\mathrm{db} / \mathrm{db}$ mice, but not in heart $(95.7 \pm 6.1 \%$, NS), in diaphragm 
Table I. Comparison between Body Weight, Fed Plasma Glucose and Insulin, and Pancreatic Insulin and Proinsulin mRNA Concentrations in 5-wk-old Obese (db/db) Mice and Their Lean Littermates (db/+)

\begin{tabular}{|c|c|c|c|c|c|c|c|}
\hline \multirow[b]{2}{*}{ Strain } & \multirow[b]{2}{*}{ Body weight } & \multirow[b]{2}{*}{ Plasma glucose } & \multirow[b]{2}{*}{ Fed plasma insulin } & \multicolumn{4}{|c|}{ Pancreatic } \\
\hline & & & & Wt & Insulin & RNA & Proinsulin mRNA/RNA \\
\hline & $g$ & $m g / d l$ & $n g / m l$ & $m g$ & $\begin{array}{c}\text { ng/mg } \\
\text { pancreas }\end{array}$ & $\begin{array}{l}\text { } \mu g / m g \\
\text { tissue }\end{array}$ & $p g / \mu g$ \\
\hline \multicolumn{8}{|c|}{ C57BL/KsJ } \\
\hline $\mathrm{db} /+$ & $21 \pm 0.6$ & $169 \pm 4$ & $1.52 \pm 0.08$ & $127 \pm 9.8$ & $112 \pm 22$ & $16.3 \pm 2.5$ & $3.49 \pm 0.4$ \\
\hline $\mathrm{db} / \mathrm{db}$ & $35 \pm 0.9^{*}$ & $663 \pm 60^{*}$ & $14.9 \pm 0.53^{*}$ & $129 \pm 9.8$ & $25 \pm 5^{*}$ & $12.3 \pm 2.5$ & $6.07 \pm 0.4^{*}$ \\
\hline
\end{tabular}

Mean \pm SEM, $n=5 . \quad{ }^{*}$ C57BL $/ \mathrm{KsJ}, \mathrm{db} /+$ vs. $\mathrm{db} / \mathrm{db}, P<0.05$.

$(75.2 \pm 12.1 \%$, NS), or in adipose tissue $(120.8 \pm 19.9 \%$, NS). The mRNA levels were consistent when expressed relative to tissue DNA as an index of cell number. The GLUT-4/actin mRNA ratio was similarly reduced in quadriceps of $\mathrm{db} / \mathrm{db}$ mice.

Muscle/adipose tissue glucose transporter protein in insulin-sensitive tissues. The level of GLUT-4 in various tissues from obese $(\mathrm{db} / \mathrm{db})$ and lean $(\mathrm{db} /+)$ mice was measured by immunoblotting using a polyclonal antisera (R820) (Table III). Quantitation was performed in two separate analyses and showed that there was no significant difference between control and $\mathrm{db} / \mathrm{db}$ mice. DNA content differed between $\mathrm{db} / \mathrm{db}$ and $\mathrm{db} /+$ mice only in adipose tissue, but GLUT -4 protein $/ \mu \mathrm{g}$ DNA did not differ $(30.7 \pm 5.4 \mathrm{cpm} / \mu \mathrm{g}$ DNA for $\mathrm{db} /+\mathrm{vs}$. $48.4 \pm 8.6 \mathrm{cpm} / \mu \mathrm{g}$ DNA for $\mathrm{db} / \mathrm{db}$ mice, mean $\pm \mathrm{SEM}, P$ $=0.11$ ). Identical data were obtained using the monoclonal antibody IF8 (data not shown). An illustrative immunoblot is shown in Fig. 1.

\section{Discussion}

Human obesity is a complex disorder that is characterized by peripheral insulin resistance. Although a cause-effect relationship between these factors has not been established, the basis for peripheral insulin resistance is being extensively studied. Previous studies have shown that skeletal muscle is the primary tissue responsible for whole body insulin resistance in human obesity (31). The regulation of glucose transport by insulin has become a focal point of studies attempting to un- derstand insulin resistance because it appears to be the ratelimiting step for glucose utilization in these tissues (23). Insulin stimulates glucose transport in muscle and adipose tissue by 10-30-fold (32-34). While the signal transduction pathway has not been established, it seems evident that a major mechanism that may account for this insulin-dependent increase in glucose transport is translocation of glucose transporters from an intracellular domain to the cell surface (32). The GLUT-4 level at the plasma membrane is increased by at least 10-fold after exposure of rat adipose tissue to insulin (10). Thus, a decrease in tissue GLUT-4 levels could conceivably result in a decreased response to insulin. In this study we have shown that in young obese mice, which have previously been shown to exhibit marked insulin resistance and impaired glucose transport in muscle, the GLUT-4 protein levels in five insulin-responsive tissues do not differ from those in their insulin-sensitive lean littermates.

Because there are obvious marked differences in body weight and degree of adiposity in obese and lean mice, we have attempted to assess the levels of glucose transporter mRNA and protein on a per cell basis by normalizing to tissue DNA content. For all tissue other than adipose tissue, neither protein, RNA, or DNA content (Tables II and III) differed between the two groups of mice. Thus for these four insulin-regulated tissues, the GLUT-4 protein and mRNA concentrations appear to be a reasonable reflection of the levels on a per cell basis. In contrast, in adipose tissue of obese mice, protein appeared to decrease $15 \%$ (NS, Table III), RNA decreased $68 \%$ (Table II, $P<0.05$ ), and DNA decreased 57\% (Table III, $P$

Table II. Muscle/Adipose Tissue Glucose Transporter (GLUT-4) and Actin mRNA Concentrations in Four Insulin-regulated Tissues (Diaphragm, Heart, Quadriceps Muscle, and Epididymal Adipose Tissue) of Obese (db/db) Mice and Their Lean (db/+) Littermates

\begin{tabular}{lcccc}
\hline \multicolumn{1}{c}{ Tissue } & Strain (C57BL/KS) & RNA & Actin mRNA & GLUT-4 mRNA \\
\hline \multirow{4}{*}{ Diaphragm } & & $\mu g /$ mg tissue & $n g / R N A \mu$ & $p g / R N A \mu g$ \\
& $\mathrm{db} /+$ & $0.96 \pm 0.31$ & $0.38 \pm 0.08$ & $141 \pm 26$ \\
Heart & $\mathrm{db} / \mathrm{db}$ & $0.94 \pm 0.24$ & $0.18 \pm 0.02$ & $106 \pm 17$ \\
& $\mathrm{db} /+$ & $0.39 \pm 0.10$ & $0.35 \pm 0.01$ & $166 \pm 13.4$ \\
Quadriceps & $\mathrm{db} / \mathrm{db}$ & $0.39 \pm 0.08$ & $0.40 \pm 0.04$ & $159 \pm 4.1$ \\
& $\mathrm{db} /+$ & $1.16 \pm 0.08$ & $0.79 \pm 0.13$ & $283 \pm 20$ \\
Epididymal adipose tissue & $\mathrm{db} / \mathrm{db}$ & $1.48 \pm 0.08$ & $0.90 \pm 0.04$ & $191 \pm 24^{*}$ \\
& $\mathrm{db} /+$ & $0.09 \pm 0.01$ & $0.15 \pm 0.02$ & $75 \pm 8.9$ \\
& $\mathrm{db} / \mathrm{db}$ & $0.029 \pm 0.004^{*}$ & $0.22 \pm 0.03$ & $95 \pm 5.8$ \\
\hline
\end{tabular}

Mean \pm SEM, $n=5 . \quad *$ C57BL $/ \mathrm{KsJ} \mathrm{db} /+$ vs. $\mathrm{db} / \mathrm{db}, P<0.05$ 
Table III. Muscle/Adipose Tissue Glucose Transporter (GLUT-4) Protein, Total Protein, and DNA in Five Insulin-regulatable Tissues of Obese $(\mathrm{db} / \mathrm{db})$ Mice and Their Lean $(\mathrm{db} /+)$ Littermates

\begin{tabular}{|c|c|c|c|c|c|}
\hline \multirow[b]{2}{*}{ Tissue } & \multirow[b]{2}{*}{ Strain (C57BL/KsJ) } & \multirow[b]{2}{*}{ DNA } & \multirow[b]{2}{*}{ Protein } & \multicolumn{2}{|c|}{ GLUT-4 protein } \\
\hline & & & & a. & b. \\
\hline & & $\mu g / m g$ tissue & $\mu g / m g$ tissue & \multicolumn{2}{|c|}{$c p m / 50 \mu g$ protein } \\
\hline \multirow[t]{2}{*}{ Diaphragm } & $\mathrm{db} /+$ & $3.1 \pm 0.7$ & $93 \pm 7$ & $982 \pm 162$ & $895 \pm 43$ \\
\hline & $\mathrm{db} / \mathrm{db}$ & $3.1 \pm 0.3$ & $83 \pm 12$ & $905 \pm 67$ & $838 \pm 49$ \\
\hline \multirow[t]{2}{*}{ Heart } & $\mathrm{db} /+$ & $4.9 \pm 0.8$ & $133 \pm 15$ & \multicolumn{2}{|c|}{$728 \pm 72$} \\
\hline & $\mathrm{db} / \mathrm{db}$ & $4.7 \pm 0.5$ & $142 \pm 9$ & \multicolumn{2}{|c|}{$656 \pm 54$} \\
\hline \multirow[t]{2}{*}{ Red quadriceps } & $\mathrm{db} /+$ & $1.6 \pm 0.1$ & $94 \pm 9$ & \multicolumn{2}{|c|}{$518 \pm 65$} \\
\hline & $\mathrm{db} / \mathrm{db}$ & $1.9 \pm 0.2$ & $115 \pm 23$ & \multicolumn{2}{|c|}{$658 \pm 148$} \\
\hline \multirow[t]{2}{*}{ White quadriceps } & $\mathrm{db} /+$ & $1.5 \pm 0.2$ & $152 \pm 15$ & \multicolumn{2}{|c|}{$26 \pm 6$} \\
\hline & $\mathrm{db} / \mathrm{db}$ & $1.6 \pm 0.2$ & $121 \pm 14$ & & \\
\hline \multirow[t]{2}{*}{ Epididymal adipose tissue } & $\mathrm{db} /+$ & $1.4 \pm 0.1^{*}$ & $14 \pm 1$ & \multicolumn{2}{|c|}{$150 \pm 25$} \\
\hline & $\mathrm{db} / \mathrm{db}$ & $0.6 \pm 0.1$ & $12 \pm 2$ & \multicolumn{2}{|c|}{$119 \pm 21$} \\
\hline
\end{tabular}

GLUT-4 protein was measured by quantitative immunoblotting as in Methods. Diaphragm a. and b. refer to repeat blots of the same samples. Mean \pm SEM, $n=5 .{ }^{*} P<0.05$ vs. db/db.

$<0.05)$ relative to that in lean mice. Furthermore, we studied adipose tissue rather than isolated cells, and the relative contribution of connective tissue to total tissue content between obese and lean mice is unknown. Yet when adipose tissue GLUT-4 RNA was assessed relative to DNA, GLUT-4 mRNA/milligram adipose tissue was greater than twofold higher in lean mice. When corrected for a greater than twofold increase in DNA/milligram adiopose tissue of lean mice, the GLUT-4 mRNA levels on a per cell basis were comparable between lean and obese mice. Similarly, adipose tissue
GLUT-4 protein when corrected for DNA did not differ between lean and obese mice.

A discrepancy between GLUT -4 mRNA and protein levels was noted in quadriceps in the present study (Tables II and III). However, we have previously documented a discrepancy in GLUT-4 mRNA and protein levels among insulin-sensitive tissues of control rats (10). In those studies, marked changes in the GLUT-4 protein per microgram total protein were noted among different muscle and adipose tissues, whereas no such differences were found in mRNA levels per microgram total
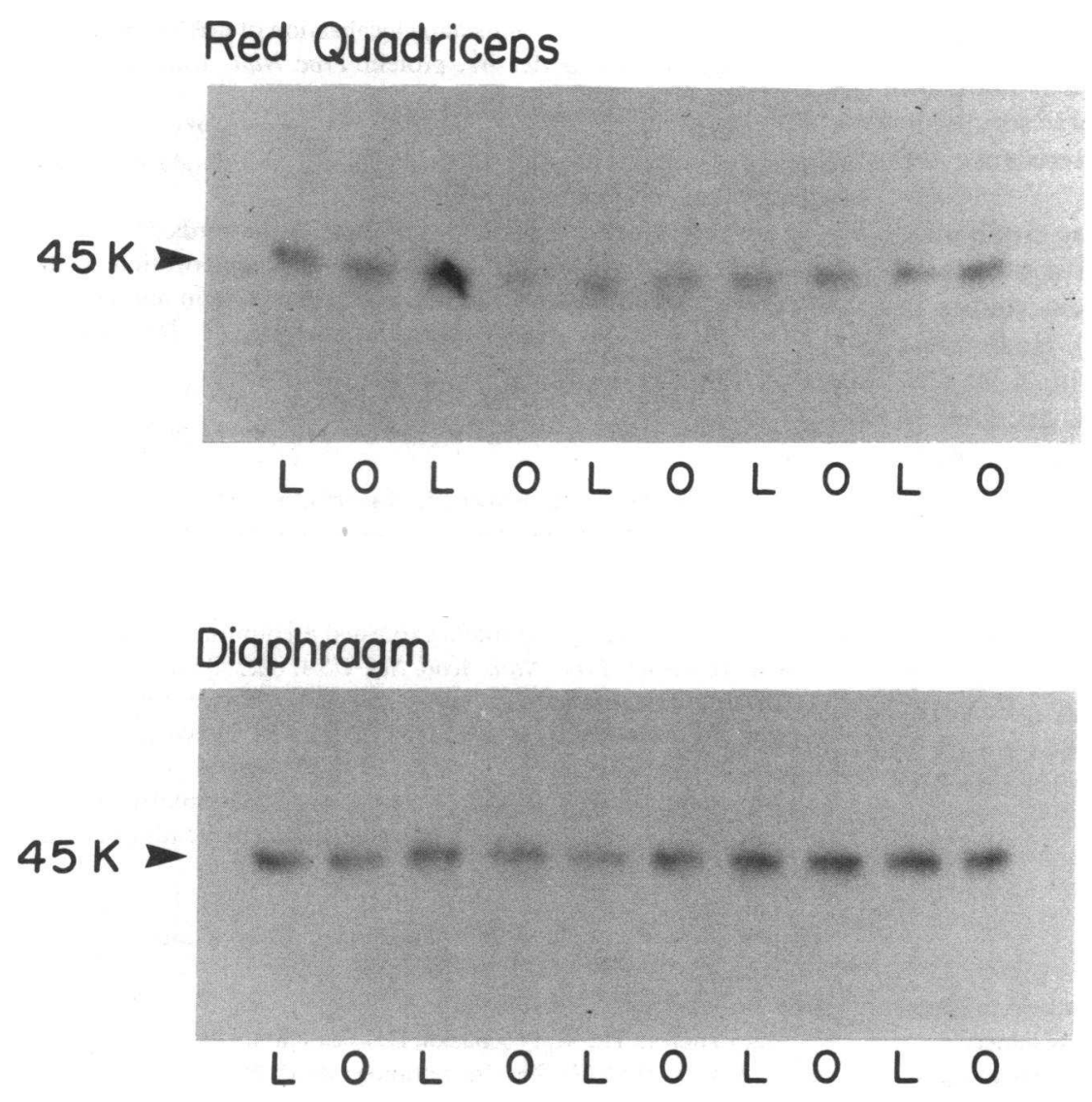

Figure 1. Muscle/adipose tissue glucose transporter (GLUT-4) protein in skeletal muscle of lean $\mathrm{db} /+(L)$ and obese $\mathrm{db} / \mathrm{db}(O)$ mice. Shown are data from 10 separate mice. Protein from red quadriceps and diaphragm was extracted, subjected to SDS PAGE, transferred to membranes, and immunoblotted with a polyclonal antibody $(\mathrm{R} 820)$ to GLUT-4 protein as described in Methods. 
RNA. Kahn et al. (24) have noted discordance between GLUT- 1 and GLUT-4 mRNA and protein levels in streptozotocin diabetic rat adipose cells treated with insulin. Thus, it is likely that transcription of the GLUT-4 gene is not proportional to the steady-state level of the protein in different tissues and/or in different metabolic states.

Insulin resistance appears to be one of the initial defects in NIDDM (35). Insulin resistance is most commonly defined by defective utilization of carbohydrates primarily by skeletal muscle and to a lesser extent adipose tissue (1, 31-33). Many animal models of obesity have proven useful for the study of NIDDM in humans because they exhibit insulin resistance in these tissues. Stauffacher and Renold (19) noted impaired glucose utilization in adipose tissue and diaphragm of 8-wk-old ob/ob mice relative to that in lean mice. Cuendet et al. (20) noted decreased uptake of 2-deoxyglucose by soleus muscle, with and without insulin, and that the maximal insulin response was less in young ob/ob mice compared with that in lean mice. Chan et al. $(21,22)$ evaluated glucose metabolism and insulin sensitivity in 5-6-wk-old $\mathrm{db} / \mathrm{db}$ mice by the perfused hindquarter method. Both basal and insulin-stimulated glucose uptake, $\left[{ }^{14} \mathrm{C}\right]$ glucose oxidation, and lactate production were diminished in obese $(\mathrm{db} / \mathrm{db})$ mice, while the half-maximal effective insulin dose did not differ. These data have led to the conclusion that the marked decrease in glucose utilization in young $\mathrm{db} / \mathrm{db}$ mouse skeletal muscle is probably due to a major defect in glucose transport. The current studies now show that this glucose transport defect in muscle is not accompanied by significant changes in the total level of insulin-regulatable glucose transporter protein. Thus, at least in this model, changes in total muscle glucose transporter can be eliminated as a cause of insulin resistance. It is noteworthy that in denervated skeletal muscle, which is also markedly insulin resistant with respect to glucose transport (36), there is no decrease in GLUT-4 protein concentration in skeletal muscle (James, D., and $\mathbf{J}$. Lawrence, unpublished data). Thus, in these seemingly different models, both of which result in insulin resistance, the total GLUT-4 protein is unaffected.

That the insulin resistance of obesity in young $\mathrm{db} / \mathrm{db}$ mice cannot be accounted for by changes in GLUT-4 protein of muscle is especially interesting in light of recent studies in adipose cells of diabetic and fasted rats (24-27). Under these conditions insulin resistance was associated with a 50-60\% decrease in GLUT-4 mRNA and a $50-87 \%$ decrease in GLUT-4 protein in adipose cells, while the translocation of glucose transporter with insulin treatment remained intact (27). These results in adipose cells (24-27) and skeletal muscle (27) of diabetic rats strongly suggested that the impaired insulin-stimulated glucose transport in this condition is due to a depletion of muscle/adipose tissue glucose transporter protein. In contrast, the insulin resistance of obese mice does not appear to be related to pretranslational changes in muscle/adipose tissue glucose transporter expression, but rather to changes in signal transduction, translocation, or functional activity of the protein.

\section{Acknowledgments}

The authors would like to thank Jeannie Wokurka for help in preparing the manuscript and Joanne Ochoa for technical assistance.

This work was supported by National Institutes of Health grants
DK16746 (to Dr. Permutt) and DK38495 (to Dr. Mueckler). Dr. Mueckler is a recipiert of a Career Development Award from the Juvenile Diabetes Foundation. L. Koranyi was a recipient of a research fellowship No. 38726y from the Juvenile Diabetes Foundation.

\section{References}

1. James, D. E., K. M. Burleigh, and E. W. Kraegen. 1985. Time dependence of insulin action in muscle and adipose tissue in the rat in vivo: an increasing response in adipose tissue with time. Diabetes. 34:1049-1054.

2. Bjorntorp, P., P. Berchtold, and J. Holem. 1971. The glucose uptake of human adipose tissue in obesity. Eur. J. Clin. Invest. 1:480485.

3. Morgan, H. E., E. Cadenas, D. M. Regern, and C. R. Park. 1961. Regulation of glucose uptake in muscle. 2. Rate limiting steps and effect. J. Biol. Chem. 236:262-268.

4. Simpson, I. A., and S. W. Cushman. 1986. Hormonal regulation of mammalian glucose uptake. Annu. Rev. Biochem. 47:503-517.

5. Wheeler, T. J., and P. C. Hinkle. 1985. The glucose transporter of mammalian cells. Annu. Rev. Physiol. 47:503-517.

6. Mueckler, M., C. Caruso, S. A. Baldwin, M. Panico, I. Blench, H. R. Morris, W. J. Allard, G. E. Lienhard, and H. F. Lodish. 1985. Sequence and structure of a human glucose transporter. Science (Wash. DC). 229:941-942.

7. Birnbaum, M. J., H. C. Haspel, and O. M. Rosen. 1986. Cloning and characterization of a cDNA encoding the rat brain glucose-transporter protein. Proc. Natl. Acad. Sci. USA. 83:5784-5788.

8. Thorens, B., H. K. Sarker, H. R. Kaback, and H. R. Lodish. 1988. Cloning and functional expression in bacteria of a novel glucose transporter present in liver, intestine, kidney, and $\beta$ pancreatic islet cells. Cell. 55:281-290.

9. Fukumoto, H., S. Seino, H. Imura, Y. Seino, R. L. Eddy, Y. Fukushima, M. G. Byers, T. B. Shows, and G. I. Bell. 1988. Sequence, tissue distribution, and chromosomal localization of mRNA encoding a human glucose transporter-like protein. Proc. Natl. Acad. Sci. USA. 85:5434-5438.

10. James, D. E., M. Strube, and M. Mueckler. 1989. Molecular cloning and characterization of an insulin-regulatable glucose transporter. Nature (Lond.). 338:83-87.

11. Fukumoto, H., T. Kayano, J. B. Buse, Y. Edwards, P. F. Pilch, G. I. Bell, and S. Seino. 1989. Cloning and characterization of the major insulin responsive glucose transporter expressed in human skeletal muscle and other insulin responsive tissue. J. Biol. Chem. 264:7776-7779.

12. Birnbaum, M. J. 1989. Identification of a novel glucose gene encoding an insulin-responsive glucose transporter protein. Cell. 57:305-315.

13. James, D. E., R. Brown, J. Navarro, and P. F. Pilch. 1988 Insulin-regulatable tissues express a unique insulin sensitive glucose transport protein. Nature (Lond.). 333:183-185.

14. Charron, M. J., F. C. Brosium III, S. L. Alper, and H. F. Lodish. 1989. A glucose transport protein expressed predominately in insulinresponsive tissues. Proc. Natl. Acad. Sci. USA. 86:2535-2539.

15. Coleman, D. L. 1978. Obese and diabetes: two mutant genes causing diabetes-obesity syndromes in mice. Diabetologia. 14:141148.

16. Orland, M. J., and M. A. Permutt. 1987. Quantitative analysis of pancreatic proinsulin mRNA in genetically diabetic $(\mathrm{db} / \mathrm{db})$ mice. Diabetes. 36:341-347.

17. Kaku, K., M. Province, and M. A. Permutt. 1989. Genetic analysis of obesity-induced diabetes associated with a limited capacity to synthesize insulin in C57BL/Ks mice: evidence for polygenic control. Diabetologia. 32:636-643.

18. Leiter, E. H., M. Prochazka, D. L. Coleman, D. V. Serreze, and L. D. Shultz. 1986. In The Immunology of Diabetes Mellitus. G. V. 
Mollnar and M. A. Jaworski, editors. Elsevier/North Holland, Amsterdam. 29-36.

19. Stauffacher, W., and A. E. Renold. 1969. Effect of insulin in vivo on diaphragm and adipose tissue of obese mice. Am. J. Physiol. 261:98-105.

20. Cuendet, G. S., E. R. Loten, B. Jeanrenaud, and A. E. Renold. 1976. Decreased basal, noninsulin-stimulated glucose uptake and metabolism by skeletal soleus muscle isolated from obese-hyperglycemic $(o b / o b)$ mice. J. Clin. Invest. 58:1078-1088.

21. Chan, T. M., and J. P. Dehaye. 1981. Hormone regulation of glucose metabolism in the genetically obese-diabetic mouse $(\mathrm{db} / \mathrm{db})$ : glucose metabolism in the perfused hindquarters of lean and obese mice. Diabetes. 30:211-218.

22. Chan, T. M., and A. Tatoyan. 1984. Glucose transport and metabolism in the perfused hindquarters of lean and obese-hyperglycemic (db/db) mice: effects of insulin and electrical stimulation. Biochim. Biophys. Acta. 798:325-332.

23. Ziel, F. H., N. Venkatesan, and M. B. Davidson. 1988. Glucose transport is rate limiting for skeletal muscle glucose metabolism in normal and STZ-induced diabetic rats. Diabetes. 37:885-890.

24. Kahn, B. B., M. J. Charron, H. F. Lodish, S. W. Cushman, and J. S. Flier. 1989. Differential regulation of two glucose transporters in adipose cells from diabetic and insulin-treated diabetic rats. J. Clin. Invest. 84:404-411.

25. Berger, J., C. Biswas, P. P. Vicario, H. V. Strout, R. Saperstein, and P. F. Pilch. 1989. Decreased expression of the insulin-responsive glucose transporter in diabetes and fasting. Nature (Lond.). 340:70-73.

26. Sivitz, W. I., S. L. DeSautel, T. Kayano, G. I. Bell, and J. E. Pessin. 1989. Regulation of glucose transporter messenger RNA in insulin-deficient states. Nature (Lond.). 340:72-74.

27. Garvey, W. T., T. P. Huecksteadt, and M. J. Birnbaum. 1989.
Pretranslational suppression of an insulin-responsive glucose transporter in rats with diabetes mellitus. Science (Wash. DC). 245:60-63.

28. Koranyi, L., M. A. Permutt, J. M. Chirgwin, and S. J. Giddings. 1989. Proinsulin I and II gene expression in inbred mouse strains. Mol. Endocrinol. 3:1895-1902.

29. Chirgwin, J. M., A. E. Przbyla, R. J. MacDonald, and W. J. Rutter. 1979. Isolation of biologically active ribonucleic acid from sources enriched in ribonuclease. Biochemistry. 18:5294-5299.

30. Labarca, C., and K. Paig̀en. 1980. A simple, rapid, and sensitive DNA assay procedure. Anal. Biochem. 102:344-352.

31. DeFronzo, R. A. 1988. Lilly Lecture 1987 . The triumvirate: $\beta$-cell, muscle, liver. A collusion responsible for NIDDM. Diabetes. 37:667-687.

32. Simpson, I. A., and S. W. Cushman. 1986. Hormonal regulation of mammalian glucose transport. Annu. Rev. Biochem. 55:10591089.

33. Garvey, W. T., T. P. Huecksteadt, S. Matthael, and J. M. Olefsky. 1988. Role of glucose transporters in the cellular insulin resistance of type II non-insulin-dependent diabetes mellitus. J. Clin. Invest. 81:1528-1536.

34. Young, D. A., J. J. Uhl, G. D. Cartee, and J. O. Holloszy. 1986. Activation of glucose transport in muscle by prolonged exposure to insulin: effects of glucose and insulin concentrations. J. Biol. Chem. 261:16049-16053.

35. Eriksson, J., A. Franssila-Kallunki, A. Ekstrand, C. Saloranta, E. Widen, C. Schalin, and L. Groop. 1989. Early metabolic defects in persons at increased risk for non-insulin-dependent diabetes mellitus. New Engl. J. Med. 321:337-343.

36. Buse, M. G., and J. Buse. 1961. The effect of denervation and insulin on the penetration of D-xylos into rat hemidiaphragms. Diabetes. 10:134-141. 